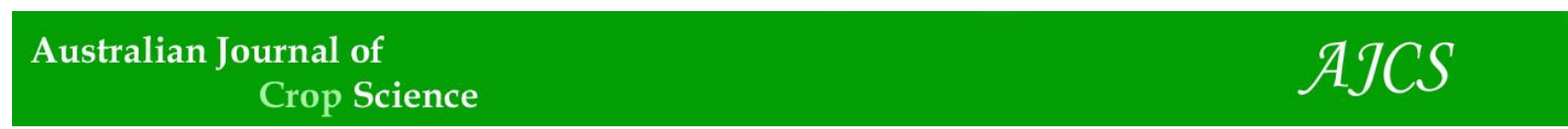

AJCS 12(01):44-50 (2018)

ISSN:1835-2707

doi: 10.21475/ajcs.18.12.01.pne623

\title{
Nitrogen and potassium fertilization on the development and chlorophyll index of irrigated wheat in the Cerrado, Central Brazil
}

\section{Danityelle Chaves de Freitas, Edna Maria Bonfim-Silva*, Tonny José Araújo da Silva, Helon Hébano de Freitas Sousa, Marcio Koetz, Alessana Franciele Schlichting, Salomão Lima Guimarães}

\author{
Federal University of Mato Grosso, Institute of Agricultural and Technological Sciences, 5055 Estudantes Ave. \\ Rondonópolis, 78.735-901, Brazil
}

\section{*Corresponding author: embonfim@hotmail.com}

\begin{abstract}
As new wheat cultivars (Triticum aestivum L.) continue to be developed, they enable cultivation in regions experiencing tropical types of climate under conditions of irrigation. However, further studies are necessary to provide details regarding the properties of the nutrients and their behavior under these conditions to advance the plant growth. Therefore, this study aimed at assessing the development of the irrigated wheat in Oxisol, using combined doses of nitrogen and potassium. These fertilizers are added in the tropical areas as a viable alternative to expand the wheat cultivable regions. Adopting the completely randomized block design, the experiment was conducted for two consecutive years in the State of Mato Grosso, Brazil. Five nitrogen doses (0, 70, 140, 210, $\left.280 \mathrm{~kg} \mathrm{ha}^{-1}\right)$, using urea as the fertilizer, and five potassium doses $\left(0,50,100,150\right.$ and $\left.200 \mathrm{~kg} \mathrm{ha}^{-1}\right)$, using Simple superphosphate as the fertilizer were employed with four replicates. Using the conventional spraying irrigation method, the plant height, number of leaves and tillers, plant lodging and chlorophyll index were assessed. The nitrogen and potassium doses were observed to influence the irrigated BRS 254 wheat in terms of the growth and chlorophyll levels. Potassium expressed the best results for the variables of this study when added alone. The addition of nitrogen demonstrated remarkable results during the second agricultural year.
\end{abstract}

Keywords: Triticum aestivum L., Fertilization management; BRS 254, Wheat Production in the Cerrado, Nitrogen and Potassium doses.

Abbreviations: DAE_Days after plant emergence, FTE_Fritted trace elements, SPAD_Soil plant analysis development.

Introduction

Wheat is extensively utilized in human consumption and has high ranked globally among the most essential cereals. As the constantly burgeoning population requires increasing food production (Ahmed et al., 2013), the availability of more cereals, like wheat, directly affects the very survival of mankind (Shahzad et al., 2013). According to Reynolds et al. (2012), one of the principal methods of increasing the wheat availability to fulfil the world-wide demand is to promote the production of wheat. However, as wheat mostly grows in the temperate zones (Goutam et al., 2013), high temperatures greatly affect the wheat by influencing the photosynthetic process (Chen et al., 2017), which in turn restricts the productivity (Webber et al., 2017). Several studies have been conducted solely to identify the genes or chemical reactions that can enhance wheat cultivation, by raising its tolerance for higher temperatures. This will facilitate expanding its regions of cultivation. This is also beneficial with the trend of rising global temperatures (Wang et al., 2014; Wana, 2015; Mishra et al., 2017). Wheat cultivars were thus tailored to adapt the tropical climatic conditions, and particularly to the edaphoclimatic factors of the Brazilian Cerrado (Cordeiro et al., 2015). The concept involved extending the cultivable areas to raise wheat production in Brazil. The Cerrado is characterized by acidic soils with poor nutrient content, low in nitrogen, phosphorus, potassium, calcium, magnesium, zinc, boron and copper concentrations but with high aluminum saturation (Lopes and Guilherme, 2016). Poorly fertile soils will restrict agricultural production if left uncorrected (van der Velde et al., 2014). For enhanced wheat development and productivity, manuring and fertilization particularly utilizing nitrogen and potassium are necessary. When nitrogen is made abundantly available, the plants absorb it and show significant improvement in growth, development, output (Benett et al., 2011; Bavar et al., 2016) and grain quality (Espindula et al., 2010).

A definite relationship between the high nitrogen doses and improved expression of the wheat gene, which was responsible for greater grain output, yield and quality (Zhan et al., 2017) has been observed. However, nitrogen added to the soil could cause environmental complications (Wang et al., 2017), as well as reduce the ability of the plant to use the nitrogen (Liu et al., 2016).

Potassium, which is the primary nutrient in plant survival and cell evolution helps in maintaining the ionic cell balance and acts as an enzyme activator, besides activating the photosynthetic enzymes (Marschner, 2012; Erel et al., 2015). 
Therefore, the plant must be provided with sufficient potassium levels to prevent any developmental loss.

The soil potassium heightens the ability of the roots to absorb the nitrate and transport it later on to the aerial plant parts (Hu et al., 2016). Potassium is vital in establishing the beneficial boundary of the intensity of interaction among these micronutrients.

Therefore, the fertilizer doses must be adjusted to suit the crop demand and reduce the negative environmental influences (Cao et al., 2017). Hence, this study aimed at assessing the development of irrigated wheat in Oxisol resulting from the effect of the combined nitrogen and potassium doses in the tropical parts of the country as a viable alternative to extend the cultivable wheat growing regions.

\section{Results and Discussions}

\section{Plant height}

In terms of plant height, the first cultivation year of the wheat (2014) demonstrated no statistical difference among the treatments. Mean plant heights of 42.8 and $46.7 \mathrm{~cm}$; therefore, were recorded for the first and second assessments, respectively.

In the second cultivation year (2015), plant height showed a significant response to the nitrogen and potassium doses during the first assessment at 37 DAE. This was observed during the elongation phases and flag leaf emergence, at which phase $10.89 \%$ the nitrogen contribution was recorded (Fig. 1A). The potassium apparently contributed $7.26 \%$ to the plant growth for the same phase (Fig. 1B).

The Cerrado region has a naturally distinctive poor fertile soil (Lopes and Guilherme, 2016); however, by implementing proper corrective management methods and appropriate fertilizers the agricultural yield showed great improvement. Thus, as this was the first crop, the plant height variable responded to the treatments more clearly only during the second year, when observable differences were reported among the treatments.

During the second agricultural year (2015), the wheat plants were assessed at $52 \mathrm{DAE}$, just when the gleaning time began; an isolated effect was recorded when nitrogen alone was applied, which increased based on the doses applied. Plant height increased by $5.8 \%$ in response to the highest nitrogen dose when compared with the treatment lacking any fertilization (Fig. 1C).

All the evaluations revealed a linear response of the plant height to the nitrogen doses applied. Hitz et al. (2017) assessed the effect of the addition of low and high nitrogen doses to the soil, and reported that the higher wheat yields were produced from the plants with the greatest heights. Belay (2014) proposed that grain yield could have a bearing on plant height, whereas stem elongation could encourage lodging, resulting in harvesting difficulties and slower grain maturation.

Although there are many processes involved with wheat development, gibberellin signaling and the expression of this hormone group are directly linked to plant height (Zhang et al., 2016), which necessitates efficient nitrogen absorption by the plants (Gooding et al., 2012). However, the addition of potassium increased the efficiency and use of nitrogen and phosphorus (Niu et al., 2013).

\section{Number of tillers}

In the first agricultural year, potassium was found to be significantly influence the number of tillers only during the first evaluation (37 days), at which the most number of tillers $\left(103.61 \mathrm{~m}^{-1}\right)$ was recorded for the potassium dose of $83.83 \mathrm{~kg} \mathrm{ha}^{-1}$ (Fig. 2A). During the second evaluation of the first agricultural year, the number of tillers per linear meter recorded no significant difference for either the added nitrogen or potassium among the treatments, with a mean of $161.25 \mathrm{~m}^{-1}$.

During the second agricultural year a significant difference was noted between the two evaluations in terms of the number of tillers, both revealing an isolated effect for the nitrogen dose applied. The first evaluation demonstrated that the nitrogen dose increased the variable, recording a $34.43 \%$ rise in tiller development (Fig. 2B). In the second evaluation, this was adjusted to the quadratic regression model. The highest number of tillers $\left(111.57 \mathrm{~m}^{-1}\right)$ was confirmed when nitrogen was applied at a dose of $198.68 \mathrm{~kg}$ $\mathrm{ha}^{-1}$ (Fig 2C). According to Cai et al. (2014) the number of tillers could be reduced when the plant density was increased per linear meter.

Recording the number of tillers can facilitate the identification of the number of spikes that plant generates, as they can survive and produce grains (Hucl and Baker, 1991). According to Cai et al. (2014) the requirement for high wheat output was influenced by population growth and development, mainly in terms of the increase in the tiller yield per unit area. The addition of potassium was observed to regulate the nitrogen metabolism, which can increase its absorption by the plant (Zahoor et al., 2017).

\section{Number of leaves}

An isolated effect was observed for the number of leaves in response to the applied potassium doses in the first evaluation of the first agricultural year. Potassium exerted a linear effect revealing a $12.81 \%$ increase $(y=312.27+$ $\left.0.2294 * \mathrm{x} ; R^{2}=0.4073\right)$. In the second evaluation on 52 (DAE), the number of leaves had a mean of 335.21 leaves per linear meter, but showed no statistical difference

During the second agricultural year (2015), the number of leaves exhibited an isolated effect in response to the nitrogen doses, for both the evaluations ( 37 and 52 DAE). The number of leaves in the first evaluation was adjusted for the nitrogen doses to the linear regression model, in which the leaf development reportedly escalated by $12.82 \%(y=$ $\left.284.77+0.1495 * x, R^{2}=0.5672\right)$. In the second evaluation, the data were adjusted to the quadratic regression model (Fig. 3), in response to the nitrogen dose of $187.08 \mathrm{~kg} \mathrm{ha}^{-1}$, which induced the production of the most number of leaves (293.35) per linear meter.

Pietro-Souza et al. (2013) assessed the wheat plant development (BRS Guamirim cV.) in the Oxisol and confirmed a spurt in the number of leaves, in response to 
Table 1. Chemical characterization of the 0-0.2 m Oxisol layer collected from the experimental area prior to the commencement of the experiment.

\begin{tabular}{|c|c|c|c|c|c|c|c|c|c|c|c|c|c|c|}
\hline $\mathrm{pH}$ & $\mathrm{Ca}$ & $\mathrm{Mg}$ & $\mathrm{Al}$ & СTC & O.M & $P$ & $\mathrm{~K}$ & $\mathrm{Zn}$ & $\mathrm{Cu}$ & $\mathrm{Fe}$ & $\mathrm{Mn}$ & $B$ & $\mathrm{~S}$ & V \\
\hline $\mathrm{CaCl}_{2}$ & ----- & $\mathrm{nol}_{\mathrm{c}} \mathrm{d}$ & -3----- & & $\mathrm{g} \mathrm{kg}^{-1}$ & & & & $--\mathrm{mg} \mathrm{d}$ & $n^{-3}-$ & & -- & & $\%$ \\
\hline 4.0 & 0.35 & 0.1 & 1.3 & 7.6 & 18.7 & 3.4 & 5 & 0. & 0.85 & 122.5 & 19 & 0.13 & 6 & 8.3 \\
\hline
\end{tabular}

Calcium Chloride $\left(\mathrm{CaCl}_{2}\right.$ ), Phosphorus (P), Potassium (K), Calcium (Ca), Magnesium (Mg), Hydrogen (H), Aluminum (Al), Sum of Bases (SB), Cation Exchan ge Capacity (CEC), Base Saturation (V) and Organic Matter (O.M).
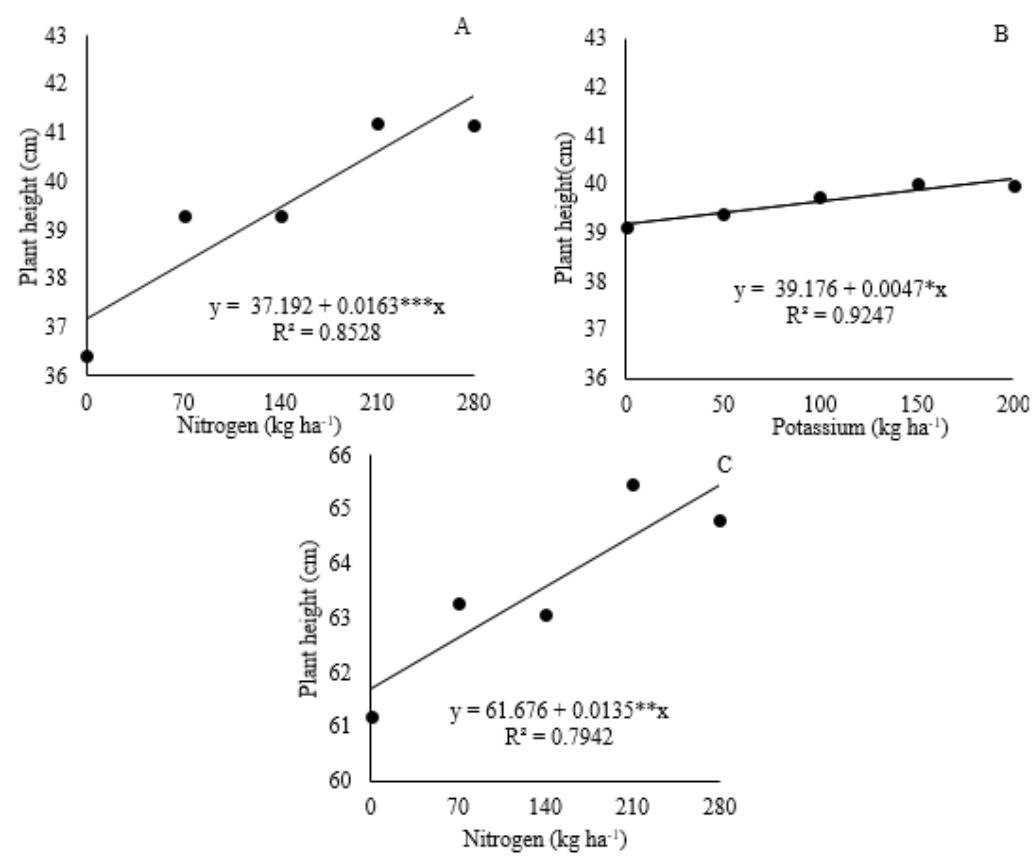

Fig 1. Plant height in the second year (2015) during the first evaluation (37 days after plant emergence) in response to the nitrogen (A) and potassium (B) doses. Plant height in the second year (2015) during the second evaluation (52 days after plant emergence) in response to the nitrogen doses (C). Significant at $* * * p<0.001, * * p<0.01$ and $* p<0.05$.
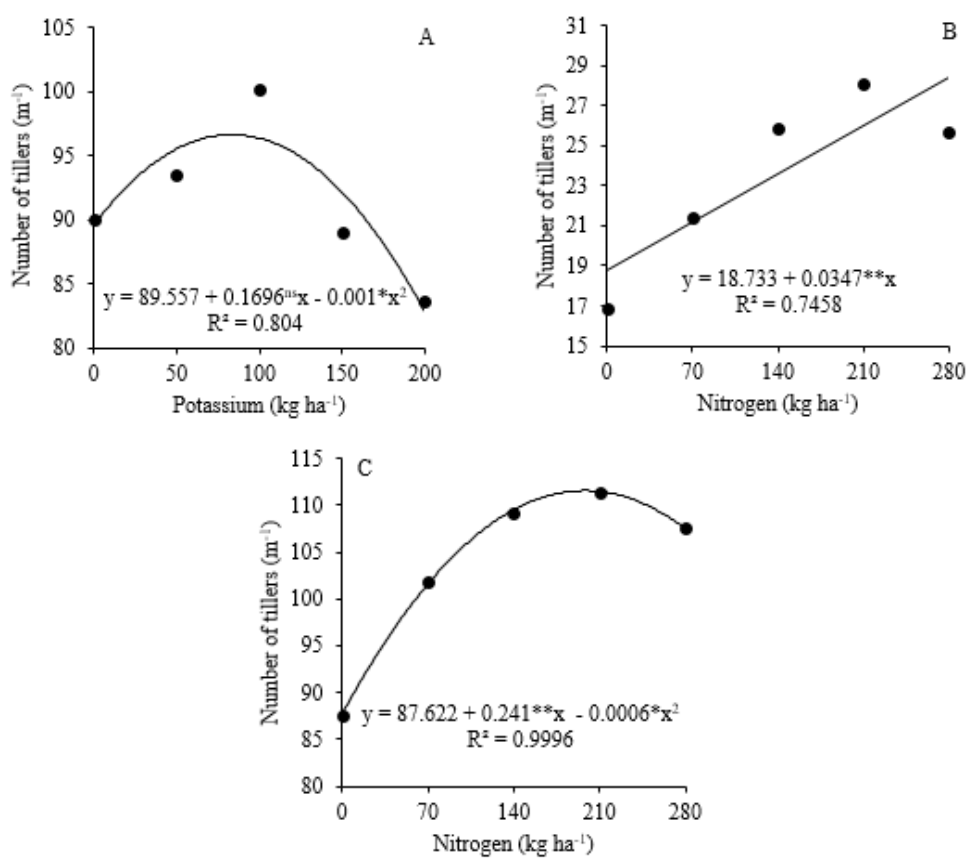

Fig 2. The number of tillers in the first evaluation of the first cultivation year, in response to the potassium (A) and nitrogen (B) doses. The number of tillers in the second evaluation of the first cultivation, in response to the nitrogen doses (C). Significant at $* *$ $p<0.01$ and $* p<0.05$. 


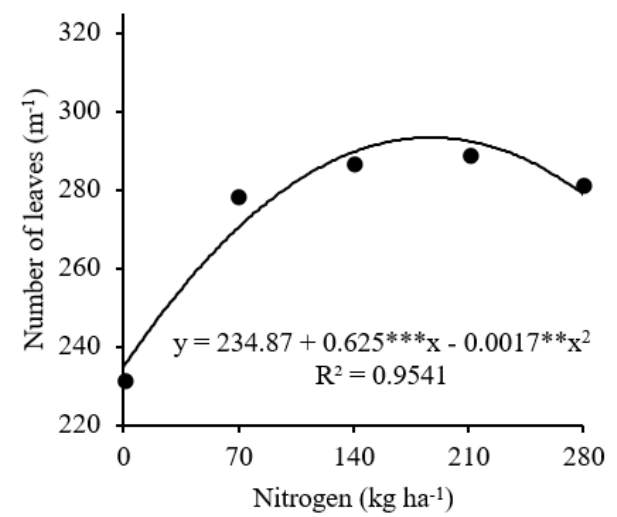

Fig 3. Number of leaves in response to the nitrogen doses in the first evaluation of the agricultural year 2015. Significant at $* * p<$ 0.01 and $* p<0.05$.

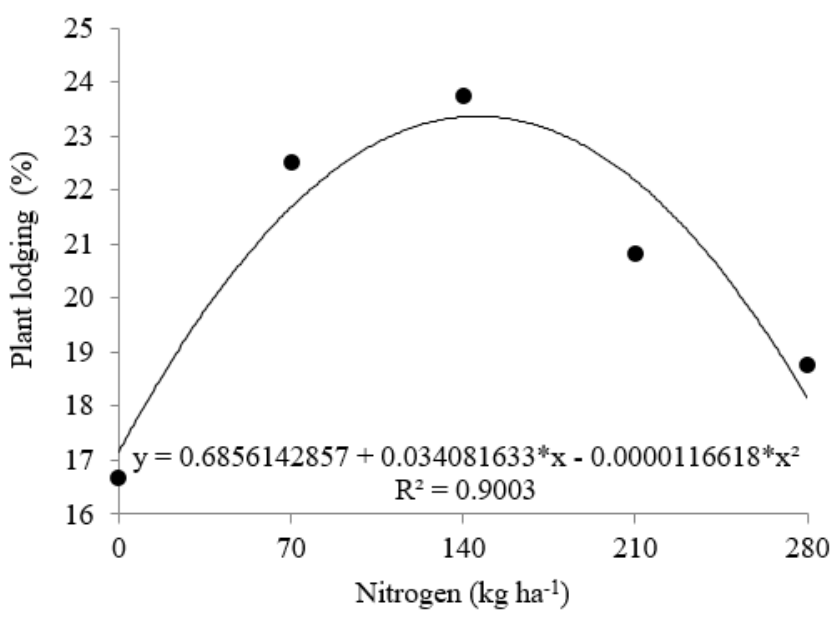

Fig 4. Plant lodging at $52 \mathrm{DAE}$, in response to the nitrogen doses, during the first agricultural year (2014). * Significant at $p<0.05$.
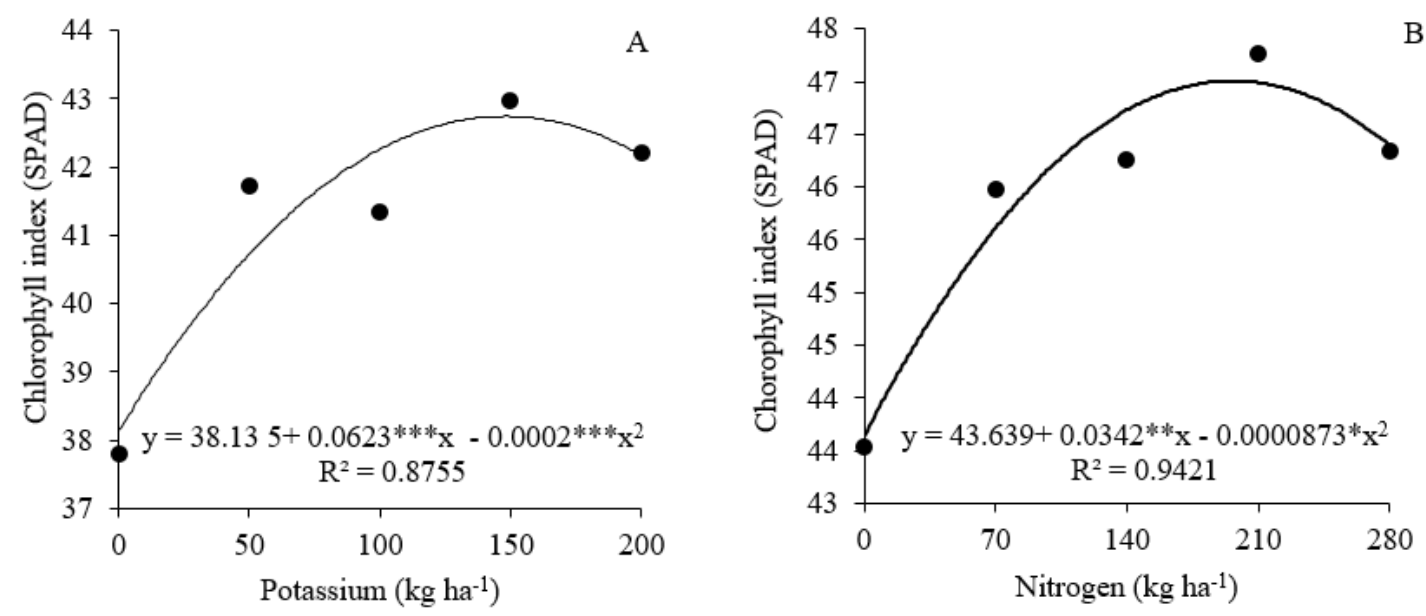

Fig 5. Chlorophyll index (SPAD), in the first evaluation of the first agricultural year (2014), in response to the potassium doses (A). The SPAD index, in the second evaluation of the second agricultural year (2015), in response to the nitrogen doses (B). Significant at $* * * \mathrm{p}<0.001, * * \mathrm{p}<0.01$ and $* \mathrm{p}<0.05$. 
the increase in nitrogen dosing. Allwood et al. (2015) confirmed that nitrogen and carbon assimilation was crucial in foliar metabolism, when they observed that the metabolite levels in the presence and absence of nitrate exerted an additional impact during the wheat leaf development.

\section{Plant lodging}

Considering the wheat plant, lodging was a significant effect evident only in the first agricultural year (2014). In the second agricultural year (2015), the mean plant lodging was $3.7 \%$. The lodging results from the first agricultural year indicated an isolated effect in the lodging in response to nitrogen alone with an adjustment to the quadratic model of regression (Fig. 4) at the $146.12 \mathrm{~kg} \mathrm{ha}^{-1}$ nitrogen dose. The highest lodging value (23.25\%) of the wheat plants was recorded at 52 DAE.

Lodging may increase the vulnerability of the wheat plants to pests and diseases (Berry et al., 2004; Pinthus, 1974), whereas the excess nitrogen fertilization can induce lodging (Subedi et al., 2007), thereby minimizing their development. The enhanced grain yield was found to be linked to the lodging resistance (Foulkes et al., 2011).

Plant lodging occurs due to root fixation failing to occur in the soil, as well as to stem spanning (Berry et al., 2004). The current study reported stem span as the sole confirmed reason.

The lignin concentrated in the second internode of the wheat plant was related to its resistance to lodging, as well as to the increased nitrogen level in the plant (Peng et al., 2014).

\section{Chlorophyll index}

During the first evaluation of the first agricultural year (2014), the chlorophyll index (SPAD) revealed an isolated effect in response to the nitrogen doses, and for the potassium doses in the second evaluation, showing adjustment to the linear and quadratic regression models, respectively. The nitrogen induced a $4.05 \%$ increase in the chlorophyll index $\left(y=43.529+0.0066^{*} x, R^{2}=0.5531\right)$. At the highest nitrogen dose $\left(280 \mathrm{~kg} \mathrm{ha}^{-1}\right)$ the chlorophyll index was 45.5 and in the absence of nitrogen fertilization $(0 \mathrm{~kg}$ ha $\left.{ }^{1}\right)$ the chlorophyll index dropped to 43.24 .

The $147.91 \mathrm{~kg} \mathrm{ha}^{-1}$ potassium dose induced the highest chlorophyll index (42.74) (Fig. 5A). Above this dose, the value of the chlorophyll index was declined, possibly because of the potassium was mobilized from the vegetative parts to the grains from the time of evaluation which was the commencement of the peeling period. Viana and Kiehl (2010) reported that the chlorophyll index increased after addition of nitrogen and potassium. Teixeira Filho et al. (2010) assessed the chlorophyll concentration in wheat plants and also confirmed that the nitrogen doses influenced the leaf chlorophyll index, in which the maximum valued achieved was 46 corresponding to the applied nitrogen dose of $147 \mathrm{~kg} \mathrm{ha}^{-1}$. The leaf nitrogen content was found directly linked to the chlorophyll index (Schlichting et al., 2015) and varied with each phenological stage (Lailibert et al., 2007). Thus, rapid and non-destructive monitoring for diagnosis of nutritional status facilitates the nutrient management strategy (Feng et al., 2015).

\section{Materials and Methods}

\section{Location and experimental design}

The experiment extended over two successive years, (2014 and 2015), from March to August of each year, in the city of Rondonópolis, State of Mato Grosso - Brazil (160 27'54.98" $\left.\mathrm{E}, 54^{\circ} 34^{\prime} 41.75^{\prime \prime} \mathrm{N}\right)$, at altitude of $287 \mathrm{~m}$. During the first and second crop years, the mean recorded temperatures were 33 and $30{ }^{\circ} \mathrm{C}$, respectively

The BRS 254 wheat cultivar experienced a medium cycle (56 days from emergence to peaking and 120 days from emergence to maturation), with a primarily erect flag leaf at the breeding time with natural resistance to threshing, moderate lodging resistance and having hard grains. This cultivar is strongly recommended for cultivation in the low altitudes in the Cerrado region (Albrecht et al., 2008). The experimental cultivation area was characterized by Oxisol (Table 1) during the first and second agricultural years. Prior to beginning of experiment the soil was limed, facilitating its ability to react for 63 days, inducing a rise of up to $60 \%$ in saturation using bases.

Employing the completely randomized block design for the experiment, with a $5 \times 5$ factorial scheme, including five nitrogen doses $\left(0,70,140,210,280 \mathrm{~kg} \mathrm{ha}^{-1}\right)$ and five potassium doses $\left(0,50,100,150\right.$ and $\left.200 \mathrm{~kg} \mathrm{ha}^{-1}\right)$, a total of 25 treatments with four replications were carried out on 100 experimental plots at all.

Each experimental plot included 9 rows, each $6.0 \mathrm{~m}$ long with $0.20 \mathrm{~m}$ spacing and $350 \mathrm{~m}^{-2}$ seed density. The useful area of each experimental plot included seven central lines, with $0.75 \mathrm{~m}$ scattering at the ends, over a total floor area of $6.3 \mathrm{~m}^{2}$. The conventional spray irrigation method was employed and managed, complying with the climatic demands observed at the Meteorological Station, as well as through the evapotranspiration values of the culture, determined using the Penman-Motith model (Allen et al., 1998). During the experimental period, water depths of 498.15 and $448.33 \mathrm{~mm}$ were employed (precipitation + irrigation), respectively, in 2014 and 2015.

For both the agricultural years (2014 and 2015), the nitrogen doses (urea) were provided in two applications. The first was found related to $30 \%$ of the dose of each treatment at the sowing time of the wheat, while the second corresponded to $70 \%$ of the dose of each treatment applied to the cover when the tillering stage began ( 14 days after the wheat emergence). Potassium fertilization (potassium chloride) was done at the time of sowing for both the agricultural years. Similar to phosphorus fertilization (single superphosphate) the addition of $200 \mathrm{~kg} \mathrm{ha}^{-1}$ and micronutrients, $30 \mathrm{~kg} \mathrm{ha}^{-1}$ included (FTE - 9\%, Zn - 1.8\%, B $0.8 \%, \mathrm{Cu}-2 \%, \mathrm{Mn}-3.5 \%$, and $\mathrm{Fe}-0.1 \% \mathrm{Mo})$. Potassium, phosphate and micronutrient fertilization were applied to the soil, in the $2-$ to $3-\mathrm{cm}$ layer just below the wheat seed during planting.

\section{Experimental evaluations}

Recordings were taken at two stages, one at 37 days post plant emergence (DAE), during the stages of flag leaf elongation and emission, and the other at $52 \mathrm{DAE}$, which was the grain-filling phase, in both the agricultural years. 
Plant height, number of leaves and tillers and chlorophyll content index were estimated.

For the first evaluation, plant height was measured from the soil surface right up to the curve of the highest fully expanded leaf. In the second, it was determined up to the tallest spike tip, barring the edges, in five randomly selected plants in the productive region of each experimental unit. At three random points (each $0.3 \mathrm{~m}$ linear), the number of leaves and tillers were counted in the productive part of each plot. Lodging was determined on a 0 to 4 scale in the experimental plots, as given: $0=$ no lodging; $1=$ up to $25 \%$ of the bedded plants; $2=$ up to $50 \%$ of the bedded plants; $3=$ up to $75 \%$ of the bedded plants; $4=$ the total number of bedded plants.

Utilizing a chlorophyll meter, the chlorophyll index was measured and the SPAD value "Soil Plant Analysis Development" was determined. Adopting the methods of Matsunaka et al. (1997), these readings were noted on diagnostic sheets $(+1$ and +2$)$ from 10 randomly selected plants in the mid-third of the first leaf blade immediately below the flag leaf, in the productive part of each experimental plot.

\section{Statistical analysis}

The analysis was done to identify the interaction between the nitrogen and potassium doses via polynomial regression (response surface). When no significant interactions were noted then first- and second-degree regressions were performed using the Statistical Analysis System (SAS). Levels up to $p \leq 0.05$ were considered significant for all the statistical tests.

\section{Conclusion}

The influence of nitrogen and potassium doses on the irrigated BRS 254 wheat cultivated under tropical climatic conditions in soils low in natural fertility was determined.

During the first agricultural year, the application of potassium alone gave the best results for the variables in this study. On the other hand, the addition of nitrogen demonstrated the most obvious results during the second agricultural year.

\section{Acknowledgments}

The authors express their gratitude to the following organizations: Coordination for the Improvement of Higher Education Personnel (CAPES), National Council of Scientific and Technological Development (CNPq), and the Research Support Foundation of the State of Mato Grosso (FAPEMAT) for the support extended for this study.

\section{References}

Ahmed M, Kamran A, Asif M, Qadeer U, Ahmed ZI, Goyal A (2013) Silicon priming: a potential source to impart abiotic stress tolerance in wheat: A review. Aust J Crop Sci. 7(4):484-491.

Albrecht JC, Silva MS, Andrade JMV, Scheeren PL, Sobrinho JS, Canovas A, Sousa CN, Ribeiro Junior WQ, Trindade MG, Sousa MA, Fronza V, Braz AJBP, Yamanaka CH (2008) BRS
254 - Trigo melhorador: cultivar com alta qualidade industrial para a região do Cerrado, Embrapa, Brasília.

Allen RG, Pereira LS, Raes D, Smith M (1998) Crop evapotranspiration: Guidelines for computing crop water requirements, $F A O$. Rome.

Allwood JW, Chandra S, Xu Y, Dunn WB, Correa E, Hopking L, Goodacre R, Tobin AK, Bowsher CG (2015) Profiling of spatial metabolite distributions in wheat leaves under normal and nitrate limiting conditions. Phytochemistry. 115:99-111.

Bavar M, Abad HHS, Noormohamadi G (2016) The effects of different levels of nitrogen on yield and yield components of rainfed wheat in two Regions of North Khorasan. Open J Ecol. 6: 443-451.

Belay M (2014) Response of different durum wheat (Triticum turgidum Var. Durum) varieties to added nitrogen fertilizer. Open Access Library J. 1: 1-7.

Benett CGS, Buzetti S, Silva KS, Teixeira Filho MCM, Andreotti M. Arf O (2011) Aplicação foliar e em cobertura de nitrogênio na cultura do trigo no cerrado. Semina: Ciências Agrárias. 32:829-838.

Berry PM, Sterling M, Spink JH, Baker CJ, Sylvester-Bradley R, Mooney SJ, Tams AR, Ennos AR (2004) Understanding and reducing lodging in cereals. Adv Agron. 84:217-271.

Cai T, Xua H, Penga D, Yina Y, Yanga W, Ni Y, Chenb X, Xua C, Yanga D, Cui Z, Wanga $Z$ (2014) Exogenous hormonal application improves grain yield of wheat by optimizing tiller productivity. Field Crops Res. 155: 172-183.

Cao H, Wang Z, He G, Dai J, Huang M, Wang S, Luo L, Sadras VO, Hoogmoed M, Malhi SS (2017) Tailoring NPK fertilizer application to precipitation for dryland winter wheat in the Loess Plateau. Field Crops Res. 209(1):88-95.

Chen Yang-Er, Zhang Chao-Ming, Su Yan-Qiu, Ma Jie, Zhang Zhong-Wei, Yuan Ming, Zhang Huai-Yu, Yuan Shu (2017) Responses of photosystem II and antioxidative systems to high light and high temperature co-stress in wheat. Environ Exp Bot. 135: 45-55.

Cordeiro MB, Dallacort R, Freitas PSL, Seabra Junior S, Santi A, Fenner W (2015) Aptidão agroclimática do trigo para as regiões de Rondonópolis, São José do Rio Claro, São Vicente e Tangará da Serra, Mato Grosso, Brasil. Agro@mbiente On-line-line. 9: 96-101.

Erel R, Yermiyahu U, Ben-Gal A, Dag A, Shapira O, Schwartz A (2015) Modification of non-stomatal limitation and photoprotection due to $\mathrm{K}$ and Na nutrition of olive trees. J Plant Physiol. 177:1-10.

Espindula MC, Campanharo M, Rocha VS, Monnerat PH, Favarato LF (2010) Composição mineral de grãos de trigo submetidos a doses de sulfato de amônio e trinexapac-etil. Pesquisa Agropecuária Trop. 40: 513-520.

Feng W, He L, Zhang Hai-Yan, Guo Bin-Bin, Zhu Yun-Ji, Wang Chen-Yang, Guo Tian-Cai (2015) Assessment of plant nitrogen status using chlorophyll fluorescence parameters of the upper leaves in winter wheat. Eur J Agron. 64: 7887.

Foulkes MJ, Slafer GA, Davies WJ, Berry PM, SylvesterBradley R, Martre P, Calderini DF, Griffiths S, Reynolds MP (2011) Raising yield potential of wheat III. Optimizing partitioning to grain while maintaining lodging resistance. J Exp Bot. 62: 469-486.

Gooding MJ, Addisu M, Uppal RK, Snap JW, Jones HE (2012) Effect of wheat dwarfing genes on nitrogen-use efficiency. J Agric Sci. 150 (01): 3-22. 
Goutam U, Kukreja S, Tiwari R, Chaudhury A, Gupta RK, Dholakia BB, Yadav R (2013) Biotechnological approaches for grain quality improvement in wheat: Present status and future possibilities. Aust J Crop Sci. 7(4):469-483.

Hitz K, Clark AJ, Van Sanford DA (2017) Identifying nitrogenuse efficient soft red winter wheat lines in high and low nitrogen environments. Field Crops Res. 200: 1-9.

Hu W, Zhao W, Yang J, Oosterhuis DM, Loka DA, Zhou Z (2016) Relationship between potassium fertilization and nitrogen metabolism in the leaf subtending the cotton (Gossypium hirsutum L.) boll during the boll development stage. Plant Physiol Biochem. 101: 113-123.

Hucl P, Baker RJ (1991) Performance of oligoculm spring wheats grown in a semiarid environment. Can J Plant Sci. 71: 199-203.

Lailiberte AS, Rango A, Herrick JE, Fredrickson Ed L, Burkett L (2007) An object-based image analysis approach for determining fractional cover of senescent and green vegetation with digital plot photography. J Arid Environ. 69:1-14.

Liu X, Xu S, Zhang J, Ding Y, Li G., Wang S, Liu Z, Tang E, Ding $C$, Chen $L$ (2016) Effect of continuous reduction of nitrogen application to a rice-wheat rotation system in the middlelower Yangtze River region (2013-2015). Field Crops Res.196:348-356.

Lopes AS, Guilherme LAG (2016) Chapter One - A Career Perspective on Soil Management in the Cerrado Region of Brazil. Adv Agron. 137:1-72.

Marschner H (2012) Mineral nutrition of higher plants, $3^{\text {rd }}$ ed. Elsevier, London.

Matsunaka T, Watanabe Y, Miyawakia T, Ichkawa N (1997) Prediction of grain protein content in winter wheat trough leaf color measurements using a chlorophyll meter. Soil Sci Plant Nutr. 43: 127-134.

Mishra D, Shekhar S, Agrawal L, Chakraborty S, Chakraborty N (2017) Cultivar-specific high temperature stress responses in bread wheat (Triticum aestivum L.) associated with physicochemical traits and defense pathways. Food Chem. 221:1077-1087.

Niu J, Zhang W, Ru S, Chen X, Xiao K, Zhang X, Assaraf $M$, Imas P, Magen H, Zhang $F$ (2013) Effects of potassium fertilization on winter wheat under different production practices in the North China Plain. Field Crops Res. 140: 69-76.

Peng D, Chen X, Yin Y, Lu K, Yang W, Tang Y, Wang Z (2014) Lodging resistance of winter wheat (Triticum aestivum L.): Lignin accumulation and its related enzymes activities due to the application of paclobutrazol or gibberellin acid. Field Crops Res. 157 (15):1-7.

Pietro-Souza W, Bonfim-Silva EM, Schlichting AF, Silva MC (2013) Desenvolvimento inicial de trigo sob doses de nitrogênio em Latossolo Vermelho de Cerrado. Rev Bras Eng Agric Amb. 17: 575-580.

Pinthus MJ (1974) Lodging in wheat, barley, and oats: the phenomenon its causes, and preventive measures. Adv Agron. 25: 209-263.

Reynolds MP, Foulkes MJ, Furbank R, Griffiths S, King J, Murchie E, Parry M, Slafer G (2012) Achieving yield gains in wheat. Plant Cell Environ. 35: 1799-1823.
Schlichting AF, Bonfim-Silva EM, Silva MC, Pietro-Souza W, Silva TJA, Farias LN (2015) Eficiência de medidores portáteis de clorofila na avaliação do estado nutricional de plantas de trigo. Ver Bras Eng Agríc. 19(12):1148-1151.

Shahzad A, Iqbal M, Asif M, Hirani AH, Goyal A (2013) Growing wheat on saline lands: Can a dream come true? Aust J Crop Sci. 7(4):515-524.

Subedi KD, Ma BL, Xue AG (2007) Planting date and nitrogen effects on Fusarium head blight and leaf spotting diseases in spring wheat. Agron J. 99:113-121.

Teixeira Filho MCM, Buzetti S, Andreotti M, Arf O, Benett CGS (2010) Doses, fontes e épocas de aplicação de nitrogênio em trigo irrigado em plantio direto. Pesquisa Agropecuária Brasileira. 45: 797-804.

van der Velde $M$, Folberth $C$, Balkovic J, Ciais $P$, Fritz $S$, Janssens IA, Obersteiner M, See L, Skalsky R, Xiong W, Penuelas J (2014) African crop yield reductions due to increasingly unbalanced nitrogen and phosphorus consumption. Glob Change Biol. 20:1278-1288.

Viana EM, Kiehl JC (2010) Doses de nitrogênio e potássio no crescimento do trigo. Bragantia. 69: 975-982.

Wana J (2015) Engineering thermotolerant plants: a solution to protecting crop production threatened by global warming. Sci Bull. 60(15):1366-1367.

Wang H, Zhang Y, Chen A, Liu H, Zhai L, Lei B, Ren T (2017) An optimal regional nitrogen application threshold for wheat in the North China Plain considering yield and environmental effects. Field Crops Res. 207:52-61.

Wang C, Wen D, Sun A, Han X, Zhang J, Wang Z, Yin Y (2014) Differential activity and expression of antioxidant enzymes and alteration in osmolyte accumulation under high temperature stress in wheat seedlings. J Cereal Sci. 60(3): 653-659.

Webber $\mathrm{H}$, Martre $\mathrm{P}$, Asseng $\mathrm{S}$, Kimball B, White J, Ottman ML, Wall GW, Sanctis G, Doltra J, Grant R, Kassie B, Maiorano A, Olesen JE, Ripoche D. Rezaei EE, Semenov MA, Stratonovitch P, Ewert F (2017) Canopy temperature for simulation of heat stress in irrigated wheat in a semiarid environment: A multi-model comparison. Field Crops Res. 202:21-35.

Zahoor R, Zhao W, Abid M, Dong H, Zhou Z (2017) Title: Potassium application regulates nitrogen metabolism and osmotic adjustment in cotton (Gossypium hirsutum L.) functional leaf under drought stress. J Plant Physiol. 215: 30-38.

Zhang M, Ma D, Ma G, Wang C, Xie X, Kang G (2017) Responses of glutamine synthetase activity and gene expression to nitrogen levels in winter wheat cultivars with different grain protein contente. J Cereal Sci. 74: 187-193.

Zhang N, Xie Yong-Dun, Guo Hui-Jun, Zhao Lin-Shu, Xiong Hong-Chun, Gu Jia-Yu, Li Jun-Hui, Kong Fu-Quan Sui Li, Zhao Zi-Wei, Zhao Shi-Rong, Liu Lu-Xiang (2016) Gibberellins regulate the stem elongation rate without affecting the mature plant height of a quick development mutant of winter wheat (Triticum aestivum L.). Plant Physiol Biochem. 107: 228-236. 